\title{
Yüksek Sıcaklıklı ve Derin Jeotermal Sahaların Rezistivite Ölçümlerinin Jeolojik Yorumlama Yöntemleri: Batı Anadolu'dan Bir Çalışma
}

\author{
Adil Özdemir ${ }^{*}$, Yıldıray Palabıyık ${ }^{2}$ \\ ${ }^{1}$ Adil Özdemir Danışmanlık, Ankara, Türkiye, (ORCID: 0000-0002-3975-2846) \\ ${ }^{2}$ İstanbul Teknik Üniversitesi, Maden Fakültesi, Petrol ve Doğal Gaz Mühendisliği Bölümü, İstanbul, Türkiye, (ORCID: 0000-0002-6452-2858)
}

(İlk Geliş Tarihi 29 Kasım 2019 ve Kabul Tarihi 30 Aralık 2019)

(DOI: 10.31590/ejosat.653203)

\begin{abstract}
ATIF/REFERENCE: Özdemir, A. \& Palabıyık, Y. (2019). Yüksek Sıcaklıklı ve Derin Jeotermal Sahaların Rezistivite Ölçümlerinin Jeolojik Yorumlama Yöntemleri: Batı Anadolu’dan Bir Çalışma. Avrupa Bilim ve Teknoloji Dergisi, (17), 1075-1091.

Öz

Düşey elektrik sondaj (DES) yöntemi, jeolojik sorunların çözümünde başvurulan başlıca jeofizik yöntemler arasında yer alır. Kayaçların yatay veya düşey yöndeki elektriksel iletkenlik farklarından yararlanılarak jeolojik yapının aydınlatılması, elektrik rezistivite (özdirenç) yönteminin uygulamasındaki temel amaçtır. Bu yöntemde, yeraltındaki tabakaların derinlikleri ve kalınlıkları özdirenç farklılıklarından faydalanılarak belirlenmeye çalışlır. Bu çalışmada, Batı Anadolu'daki yüksek sıcaklıklı ve derin bir jeotermal sahanın DES ölçümleri ile yeraltı jeolojisinin yorumlanması amaçlanmıştır. Bu amaçla, $\mathrm{AB} / 2=2500 \mathrm{~m}$ kuramsal derinlik için ölçülen 206 adet özdirenç ölçümü, EarthImager 1D and RockWorks programları ile değerlendirilmiştir. 2D-3D rezistivite ve stratigrafik enine kesitler hazırlanmış ve yorumlanmıştır. Çalışma alanında, tektonizma kontrollü olarak jeotermal faaliyet varlığını gösteren düşük rezisitivite anomalileri belirlenmiş ve kavramsal jeotermal model kurgulanmıştır.
\end{abstract}

Anahtar Kelimeler: jeotermal arama, rezistivite, jeolojik yorum, yüksek sıcaklıklı jeotermal saha, Batı Anadolu, Gediz Grabeni

\section{Geological Interpretation Methods of Resistivity Measurements of High-Temperature and Deep Geothermal Fields: A Study from Western Anatolia}

\begin{abstract}
The vertical electrical sounding (VES) method is one of the main geophysical methods used in solving geological problems. The main target for the application of the electrical resistivity method is to illuminate the geological structure by making use of the electrical conductivity differences of the rocks in the horizontal or vertical directions. In this method, depths and thicknesses of formation layers in the subsurface are attempted to be determined by utilizing resistivity differences. In this study, it is aimed to interpret the subsurface geology of a high-temperature and deep geothermal field in Western Anatolia by DES measurements. For this purpose, 206 resistivity measurements, measured for $\mathrm{AB} / 2=2500 \mathrm{~m}$ theoretical depth, have been evaluated by using EarthImager $1 \mathrm{D}$ and RockWorks programs. 2D and 3D resistivity along with stratigraphic cross-sections have been prepared and interpreted. In the study area, low-resistivity anomalies indicating the presence of geothermal activity controlled by tectonism have been determined and a conceptual geothermal model has been designed.
\end{abstract}

Keywords: geothermal exploration, resistivity, geological interpretation, high-temperature geothermal field, Western Anatolia, Gediz Graben

\footnotetext{
* Sorumlu Yazar: Adil Özdemir, Ankara, Türkiye, ORCID: 0000-0002-3975-2846, adilozdemir2000@yahoo.com
} 


\section{Giriş}

Çalışma alanının yer aldığı Gediz Grabeni’ndeki (Batı Anadolu) ilk jeotermal çalışmalar, yüksek sıcaklıklı sıcak su kaynaklarının varlığ 1 nedeniyle 1960 'lı yıllarda başlamıştır (Şekil 1). Son yıllarda yapılan sondajlarla, $28{ }^{\circ}{ }^{\circ}$ 'ye kadar jeotermal akışkanlar üretilmiştir (Özdemir ve diğ., 2017). Jeotermal kaynaklar, başlıca elektrik üretiminde olmak üzere bölgesel ve sera 1sitması, kimyasal madde üretimi ve sağlık turizminde kullanılmaktadır. Gediz Grabeni’nde 200'den fazla derin jeotermal kuyu açılmıştır. 6 adet jeotermal elektrik santrali (JES) çalışmaktaDIR. Çalışma alanının stratigrafisi, petrografisi ve tektoniği (MTA, 2010a, 2011a; Öner, 2012; Koçyiğit, 2014; Özdemir ve Palabıyık, 2019a; Palabıyık ve Özdemir, 2019), petrol etüdü (Yazman ve İztan, 1990; Yazman ve diğ., 1998), jeotermal etüdü (Ünal ve Havur, 1971; Y1lmazer ve diğ., 2010; Özdemir, 2015; Özdemir ve diğ., 2017), rezisitivite etüdü (Şener ve diğ., 1993; FNÇ, 2012), gravite ve manyetik etüdü (MTA, 2010a,b), sismik ve gravite etüdü (Erden, 1965; Gürsoy, 1981; Yazman ve diğ., 1998; Türk, 2014), manyetotellürik etüdü (WesternGeco, 2012; Özdemir ve Palabıyık, 2019b) hidrotermal alterasyon çalışmaları, hidrojeolojik ve su kimyası değerlendirmeleri (MTA, 2011b,c ve Şimşek, 2012), sondaj ve kuyu tamamlama çalışmaları (MTA, 2011a,b,c,d,e,f) ile ilgili çok sayıda çalışma yapılmıştır. İnceleme alanında, tabandan tavana doğru sırayla, (1) PrekambriyenOrta Triyas yaşlı Menderes Masifi'ne ait metamorfik kayaçlar (gnays, kalkşist, kuvarsşist, fillit, mikaşist), (2) Paleozoik yaşlı mermerler (3), granitik kayaçlar, (4) Üst Miyosen-Alt Pliyosen yaşlı çökellerle karakterize Gediz formasyonu, (5) Üst PliyosenKuvaterner yaşlı çökellerle karakterize Kaletepe formasyonu ve (6) Kuvaterner yaşlı alüvyonlar olmak üzere 6 farklı birim ayırt edilmiştir (Şekil 2) (Özdemir ve diğ., 2017).

Düşey elektrik sondaj (DES) yöntemi, jeolojik sorunların çözümünde başvurulan başlıca jeofizik yöntemler arasında yer alır. Kayaçların yatay veya düşey yöndeki elektriksel iletkenlik farklarından yararlanarak, jeolojik yapının aydınlatılması elektrik özdirenç yönteminin uygulamasındaki temel amaçtır. $\mathrm{Bu}$ yöntemde, yeraltındaki tabakaların derinlikleri ve kalınlıkları özdirenç farklılıklarından faydalanılarak belirlenmeye çalışılır. İnceleme alanının yeraltı jeolojisi, Özdemir ve Palabıyık (2019) tarafından manyetotellürik yöntemlerle incelenmiştir. Bu çalışmada ise, öncel çalışmalarda Schlumberger yöntemi ile alınan DES ölçümleri ile çalışma alanının yeraltı jeolojisinin yorumlanması amaçlanmıştır. Bu amaçla, AB/2 $=2500 \mathrm{~m}$ kuramsal derinlik için ölçülen 206 adet özdirenç ölçümü (DES), EarthImager 1D and RockWorks programları ile yeniden değerlendirilmiştir. DES eğrileri, özdirenç ve stratigrafik enine kesitler, yeniden hazırlanmış ve yorumlanmıştır. Ölçüm noktası aralığı, 250-500 m arasında değişmektedir (Şekil 3). $\mathrm{Bu}$ çalışmada, yeniden belirlenen enine-kesit hatları boyunca tektonizma kontrollü olarak jeotermal faaliyet varlığını gösteren düşük özdirenç anomalileri belirlenmiştir.

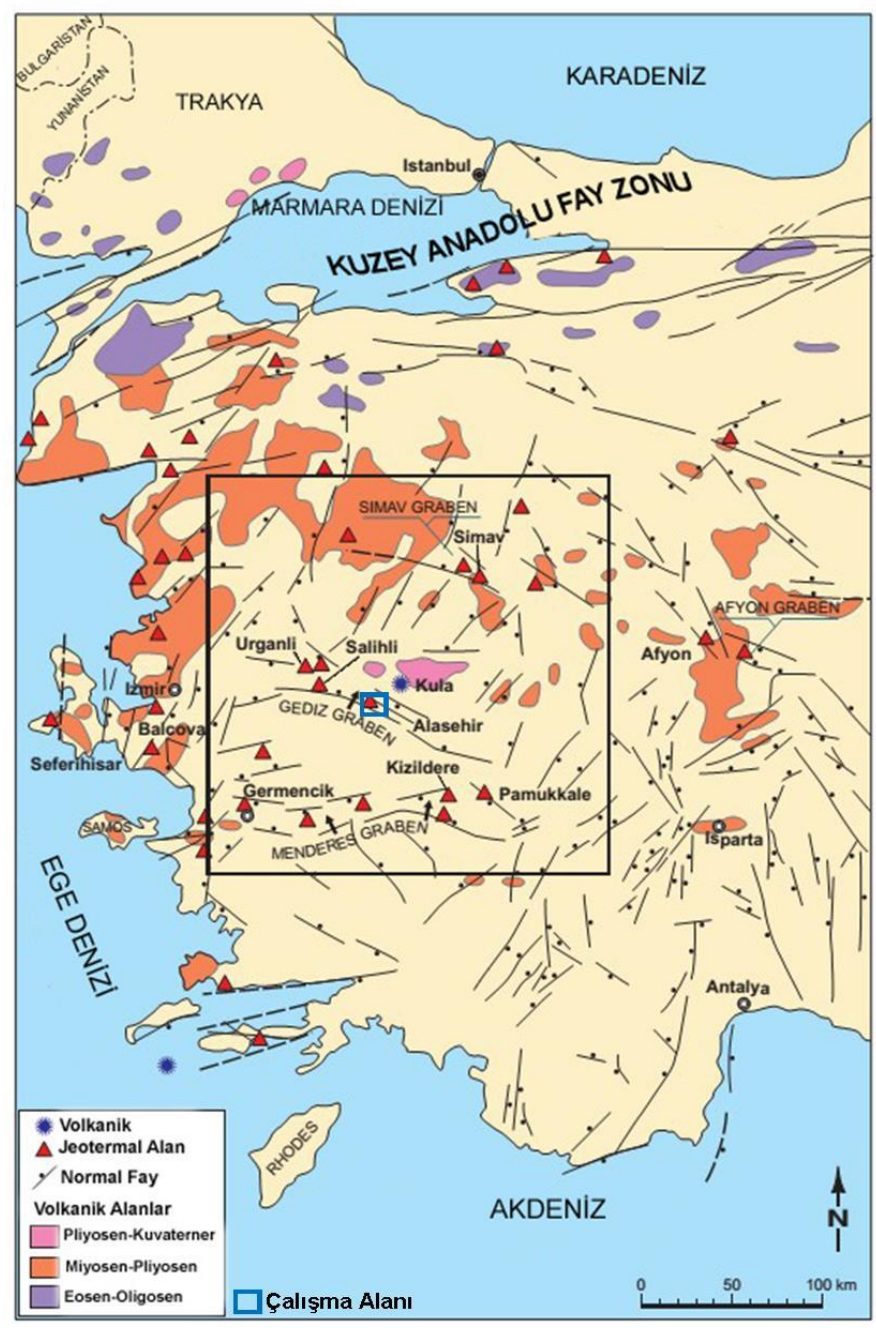

Şekil 1. Batı Anadolu'daki ana fay zonlarını ve jeotermal sistemlerin konumların gösteren jeoloji haritası (Faulds ve diğ., 2009) 


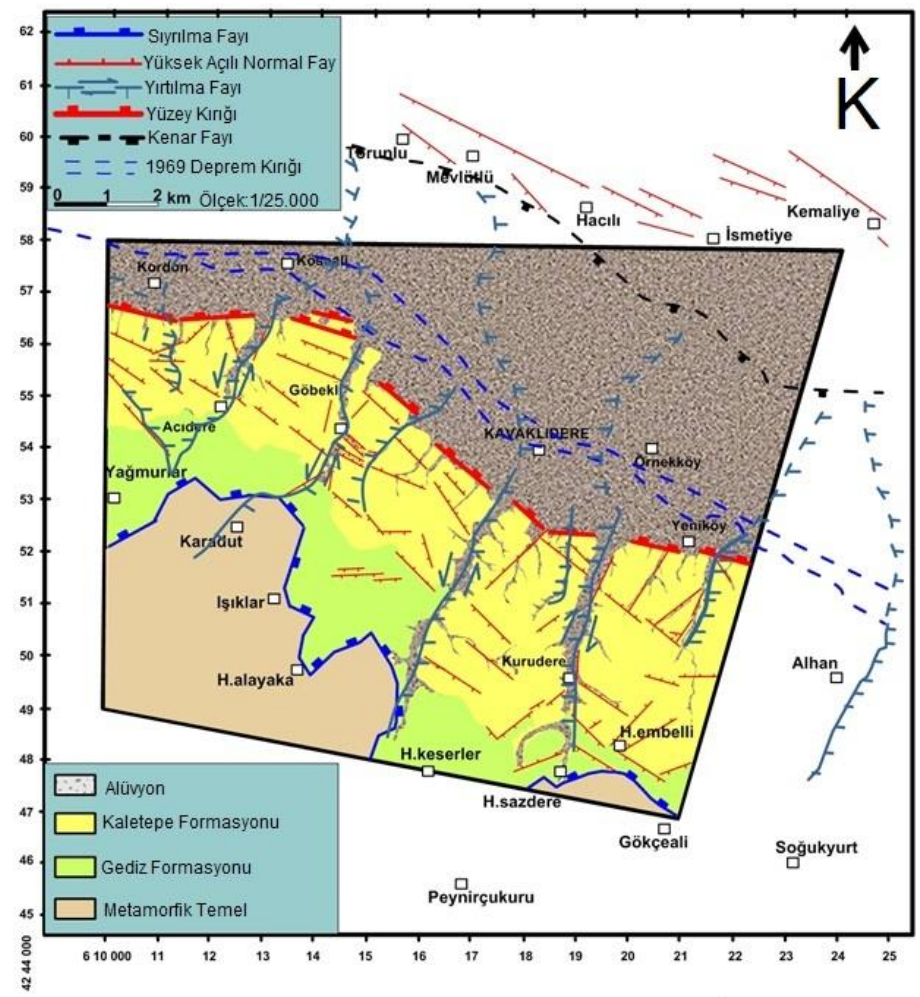

Şekil 2. Çalışma alanının basitleştirilmiş jeoloji haritası (Özdemir ve diğ., 2017)

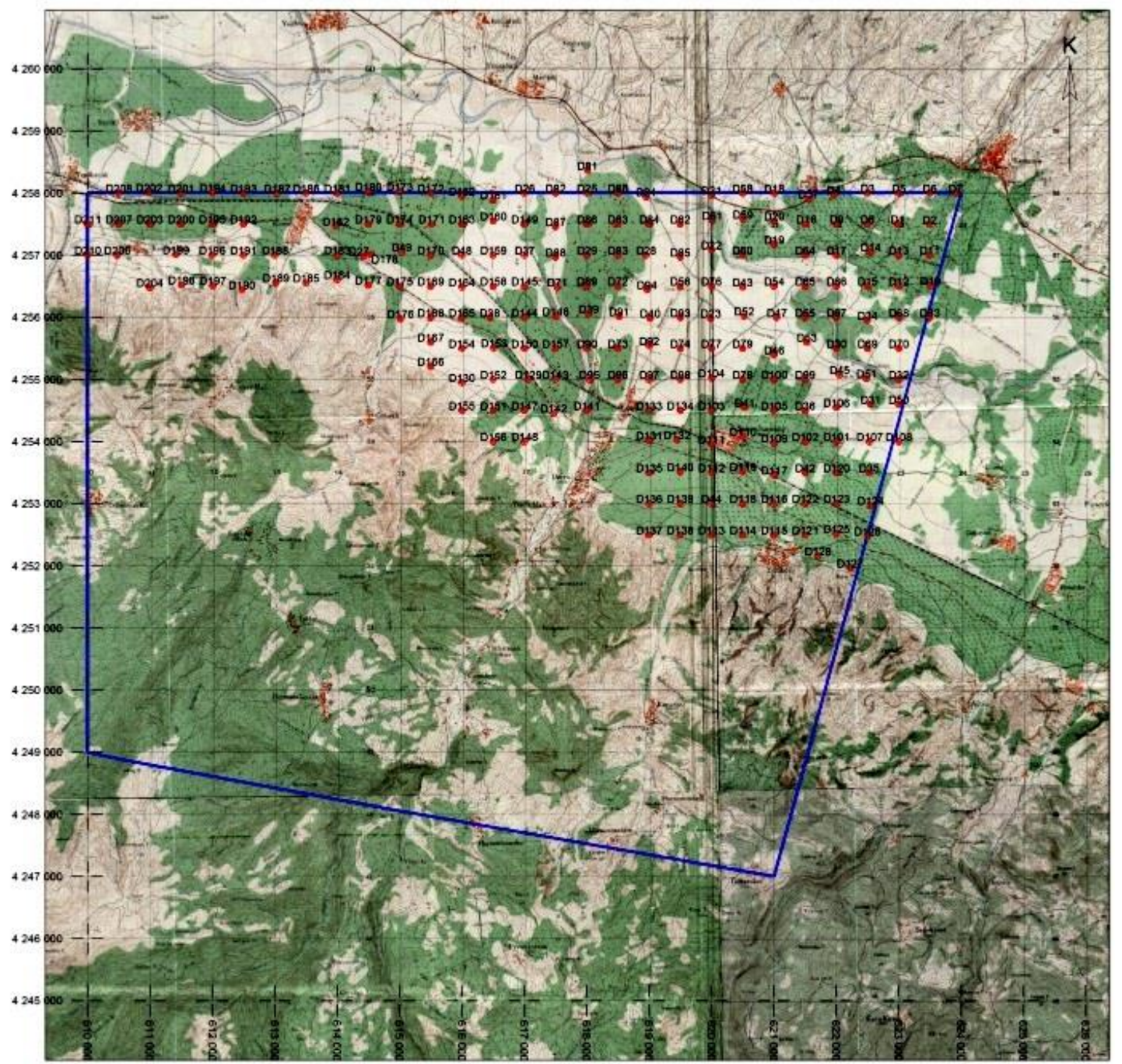

Şekil 3. Çalışma alanındaki düşey elektrik sondaj (DES) ölçüm noktalarının yer bulduru haritası (UTM -ED50) 


\section{Jeofizik Rezisitivite Ölçümleri}

Elektriği iyi ileten ortamların özdirenç değeri düşük, elektriği iletmeyen ortamların özdirenç değeri yüksektir. Bu ilkeden hareketle, içerisinde su bulunan formasyonların iletkenlikleri yüksek, dolayısı ile özdirençleri düşük olacaktır. Mineral çözeltisi içeren suların bulunduğu formasyonların özdirenç değerleri ise, daha da düşük olacaktır. Ortamın özdirencini etkileyen birçok etken vardır. Bunlar; jeolojik birimlerin gözenekliliğindeki değişimler, içerdiği çözeltilerin kimyasal durumları, yoğunluklarındaki farklılıklar ve 1sı değişimleri gibi etkenlerdir. Özellikle, jeotermal bir sistemin bu tür değişimlerin tümünü barındırması ile ortamda bulunan farklı ve hızlı değişen fiziksel özelliklerin yöntemin başarısını etkilediği bilinen bir gerçektir. Jeotermal bir alan üzerinde yapılan özdirenç araştırmasında, ortamın 1sı, gözeneklilik, tuzluluk ve iyonik mineral oranındaki artış, doygun kayacın özdirencini azaltıcı etkenlerdir. $\mathrm{Bu}$ önemli olgu, jeotermal sistemin belirlenmesinde etkilidir. Ayrıca, hidrotermal etkinlikler sonucu oluşmuş kil minerallerinin varlığı da, ortamın özdirencinin belirlenmesinde önemli bir etkiye sahiptir. Bu etkilerin tümü, özdirencin düşmesine neden olur ve akışkan içeren jeotermal sistemlerin tümünde gözlenir. Ancak, sıvı baskın yerine buhar baskın rezervuarlar üzerinde yapılan özdirenç araştırmaları, bu tür rezervuarların göreli olarak daha yüksek özdirenç değerleri verdiğini de ortaya koymuştur. Doğaldır ki, bu tür rezervuarların suya doygun bölümleri de düşük özdirençli zonlarla tanımlanabilir. Jeotermal alanlar, tektonik aktivitenin etkin olduğu ve önemli değişimler geçirmiş yerlerde bulunmaktadır. Böylece, jeolojik açıdan birçok değişik türde süreksizliğe sahiptirler. Bu özellik, gömülü rezervuarın bilinmeyen, tanımlanmamış ve boyutları düşünüldüğünde de oldukça karmaşık olan yapısı için birçok belirsizliğe neden olabilir. Ancak, ortamda sıcak tuzlu sular ve kil içeriğinin bulunduğu durumlarda, ortamlar arasındaki yüksek özdirenç zıtlığının ortaya çıkması, çözümü bir ölçüde kolaylaştırıcı bir etken olmaktadır. Jeofizik literatüründe, jeotermal aramacılıkta kullanılan özdirenç yöntemleri üzerine birçok araştırma bulunmaktadır ve çok sayıda jeotermal rezervuar bu yöntem yardımıyla araştırılmışıtr.

Özdirenç (rezistivite) yöntemi, gömülü hidrotermal yapının boyutlarını belirlemek ve onları jeotermal rezervuarlarla ilgili termal ve hidrojeolojik yapılarla ilişkilendirmek için Schlumberger veya Wenner elektrot dizilimi kullanılarak gerçekleştirilebilir. İnceleme alanındaki öncel özdirenç çalışmalarında, düşey elektrik sondajı (DES) için, Schlumberger yöntemi ile ölçüler alınmıştır. DES ölçümleri, 206 lokasyonda gerçekleştirilmiştir (Şekil 3). DES ölçümlerinde $A B / 2=2500$ m kuramsal derinlik araştırılmıştır. Ölçüm noktası aralı̆̆ı, 250-500 m arasında değişmektedir. Bu çalışma kapsamında, öncel çalışmalarda ölçülen özdirenç ölçümleri, EarthImager 1D and RockWorks 15 programları ile yeniden değerlendirilmiştir. DES eğrileri, özdirenç ve stratigrafik enine kesitler yeniden hazırlanmış ve yeniden yorumlanmıştır. Bu çalışmada, yeniden belirlenen enine-kesit hatları boyunca tektonizma kontrollü olarak jeotermal faaliyet varlığını gösteren düşük özdirenç anomalileri arasındaki ilişki belirlenmiştir. Bu sayede, düşey elektrik sondaj (DES) ölçümleri ile yüksek sıcaklıklı bir sahanın jeotermal enerji olanaklarını araştırma metodolojisine katkıda bulunmak amaçlanmıştır. Çalışma alanındaki sedimanter birimlerin (örtü kayaçların) toplam kalınlığının, sedimanter kayaçlar altında bulunan temel kayaçların derinliğinin ve buna bağlı olarak temel kaya topoğrafyasının çıkarılması, yeraltı jeolojisinin ve jeotermal sistemi kontrol eden tektonik yapıların belirlenmesi, muhtemel jeotermal etkinliğin oluştuğu alanlar ve seviyelerin belirlenmesi, sıcak akışkanın yüzey jeolojisi, yeraltı jeolojisi ve tektonizma ile olan ilişkisini tanımlayarak olası jeotermal sistem özelliklerinin belirlenmesi hedeflenmiş̧ir. Çalışma alanında delinmiş olan jeotermal kuyular vardır ve bu kuyularda değişik debilerde ve yüksek sıcaklıkta akışkan birlikteliği sağlanabilmiştir. Dolayısıyla, bu çalışmada, delinmiş olan bu kuyulara ait veriler de dikkate alınmıştır.

Seviye haritaları, farklı derinliklerdeki özdirenç dağılımlarını gösterir. Bu haritalardan, farklı derinliklerdeki tektonik yapının ve jeotermal akışkan içeren seviyelerin yanal ve düşey yöndeki değişiminin izlenmesi mümkündür. $\mathrm{Bu}$ amaca uygun olarak, farklı kuramsal derinlikler için 18 adet özdirenç seviye/derinlik haritası hazırlanmıştır. Seviye haritaları, AB/2 = $900 \mathrm{~m}, 1000 \mathrm{~m}, 1100 \mathrm{~m}$, $1200 \mathrm{~m}, 1250 \mathrm{~m}, 1300 \mathrm{~m}, 1400 \mathrm{~m}, 1500 \mathrm{~m}, 1600 \mathrm{~m}, 1700 \mathrm{~m}, 1750 \mathrm{~m}, 1800 \mathrm{~m}, 1900 \mathrm{~m}, 2000 \mathrm{~m}, 2100 \mathrm{~m}, 2200 \mathrm{~m}, 2300 \mathrm{~m}, 2400 \mathrm{~m}$ ve $2500 \mathrm{~m}$ kuramsal derinlikler için hazırlanmıştır. Enine kesitler, seviye ve temel derinliği haritaları hazırlanırken minimum düşük özdirençli seviyelerin daha net olarak belirlenebilmesi için maksimum özdirenç değeri $80 \mathrm{ohm}$.m olarak sınırlandırılmıştır

Temel derinliği haritası, elektriksel temel olan kalın ve iletken sedimanter istifin altındaki yüksek özdirençli kayaçların derinliğini gösteren haritadır. Bu haritadaki derinlik verileri, ölçülen 206 adet DES noktasının eğrilerinin EarthImager 1D yazılımı ile yeniden değerlendirilmesi sonucunda belirlenmiştir. Derinlik haritası, metamorfik kayaçların üzerindeki sedimanter kayaçların toplam kalınlı̆̆ını göstermektedir. Derinlik boyutunda, havzadaki temel kayanın topoğrafyası ve yapısı izlenebilmektedir. Bu harita, özellikle sondaj kuyularının yerlerinin belirlenmesi için önemlidir.

\subsection{Sı ̆̆ Seviyelerin Özdirenç Dağılım Haritaları ve Yorumları}

Öncel jeolojik çalışmalardan elde edilen verilere göre, 900-1500 metreler sı̆ seviye olarak tanımlanmış ve AB/2 = 900 - 1500 metreler için özdirenç seviye haritaları hazırlanmıştır (Şekil 4 ve 5). Jeotermal faaliyet ile doğrudan bağlantılı olmayan düşük özdirenç değerleri, örtü kayaçların değerleri olarak yorumlanmıştır. Ancak, sahanın bazı bölümlerinde görülen özdirenç düşüşü, jeotermal etki ile bağlantılı olarak yorumlanmıştır. Başka bir deyişle, sahanın derin seviyeleri için hazırlanan özdirenç haritalarında, jeotermal sistem ile ilişkili olan bölgelerin üst kısımlarında görülen düşük özdirenç değerleri, jeotermal etkinliğin özdirenç değerlerine yansıması olarak düşünülmüştür. 

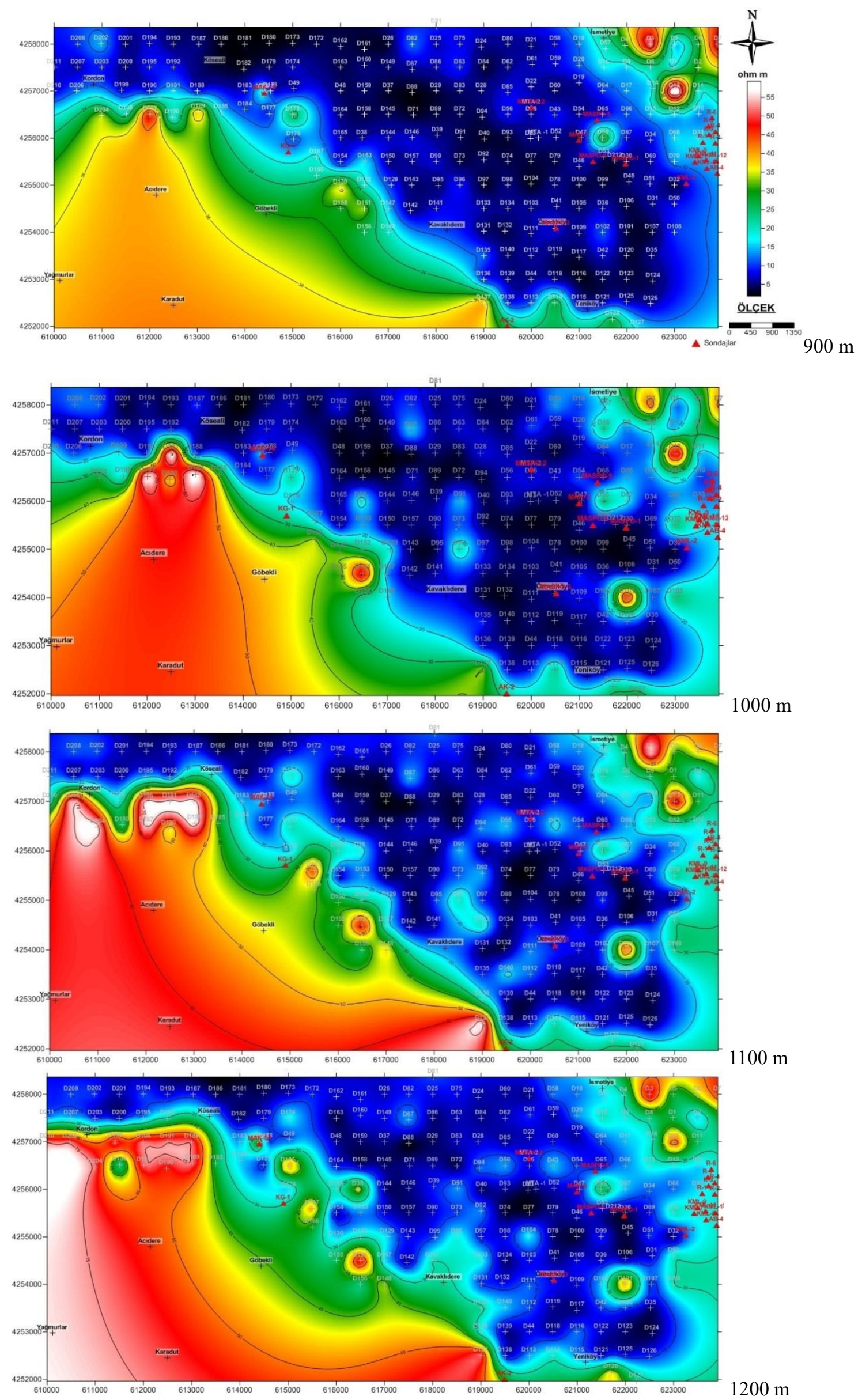

Şekil 4. AB/2=900 - 1200 metre derinlikler için özdirenç seviye haritaları 

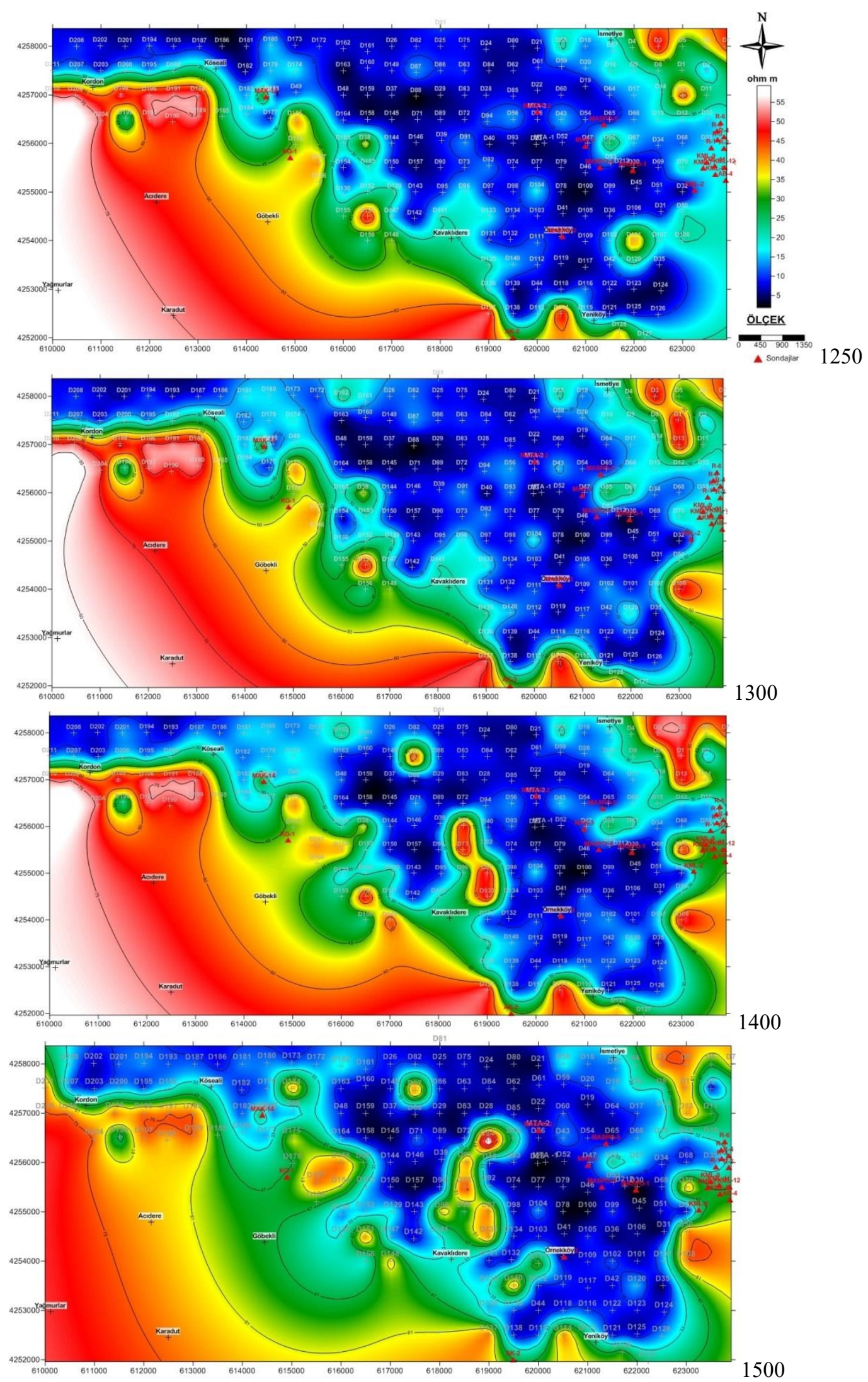

Şekil 5. AB/2=1250 - 1500 metre derinlikler için özdirenç seviye haritaları

\subsection{Derin Seviyelerin Özdirenç Dağılım Haritaları ve Yorumları}

Öncel jeolojik çalışmalarından elde edilen verilere göre, çalışma alanındaki 1500-2500 metreler derin seviyeler olarak tanımlanmıştır. Bu sebeple, derin seviye incelemesi amacıyla $\mathrm{AB} / 2=1500-2500$ metreler için özdirenç seviye haritaları hazırlanmıştır (Şekil 6-8). Bu seviye haritalarında, çalışma alanın kuzey-kuzeydoğu bölümünde düşük özdirenç kapanımları tespit edilmiştir. 

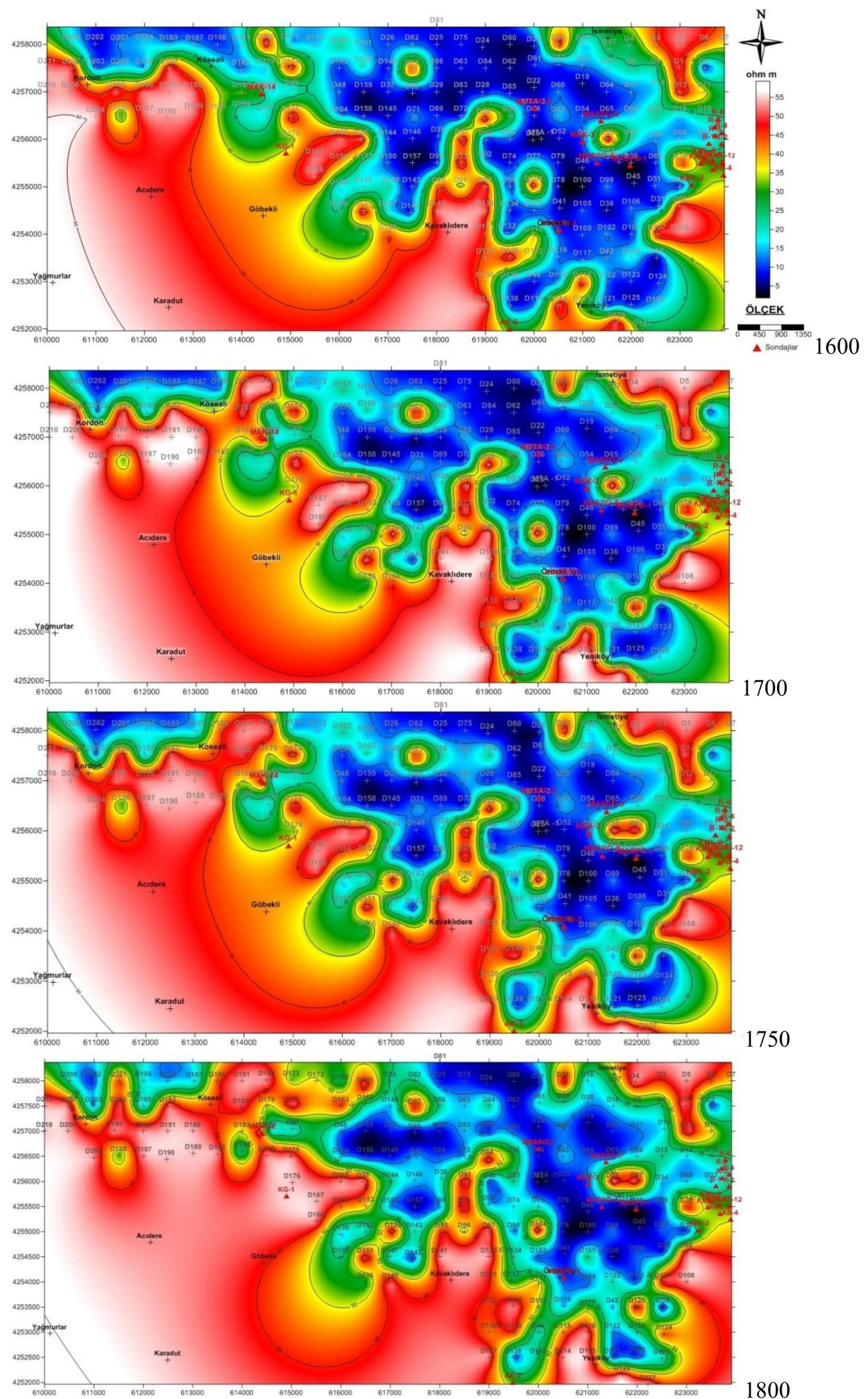

Şekil 6. AB/2=1600 - 1800 metre derinlikler için özdirenç seviye haritaları

$\mathrm{AB} / 2=1500-1600$ metre kuramsal derinliklerde (Şekil 5 ve 6), çalışma alanının kuzey-kuzeydoğu bölümü, düşük özdirenç değerine sahiptir. 1600-1750 metre kuramsal derinliği gösteren özdirenç haritalarında görülen özdirenç dağılımı göz önünde bulundurularak, bu derinliklerdeki jeotermal etki açık hale gelmektedir. Derin seviyelerde, fay sistemleri ile ilgili düşük özdirenç alanlarının yaygınlığı, derinlik arttıkça jeotermal potansiyelin de arttığı şeklinde yorumlanmıştır.

$\mathrm{AB} / 2=1750-1900$ m kuramsal derinlikleri gösteren özdirenç seviye haritalarında (Şekil 6 ve 7), en düşük özdirenç dağılımı net olarak tespit edilebilmektedir. Bu haritalarda, çalışma alanının kuzey-kuzeydoğu bölümünde, jeotermal enerji potansiyelinin en güçlü belirteci olan rezistivite değeri en düşük değerlere ulaşmıştır. Havza dolgu çökellerinin, derin seviyelerinde çok düşük özdirenç 


\section{Avrupa Bilim ve Teknoloji Dergisi}

değerlerinin ölçülmesi, temel kaya içerisindeki yüksek sıcaklıklı akışkanların, örtü kayada oluşturduğu alterasyon ve buna bağlı olarak oluşan elektrolitik ortamla açıklanabilir.

$\mathrm{AB} / 2=1900-2500$ metre kuramsal derinliklerini yansıtan özdirenç haritalarında (Şekil 7 ve 8), genel görünüm oldukça farklıdır. $\mathrm{Bu}$ haritalardaki rezistivite değerlerindeki göreceli yükselişi, bu seviyelerde temel birimlere girildiğini göstermektedir. Fakat, bu haritalarda görülen rezistivite, temel birimlerin rezistivitesini tam olarak yansıtmamaktadır. Rezistivitenin çok küçük değerlere kadar düşmesi, sahadaki çökel kalınlığının fazla olması ve buna bağlı olarak temel derinliğinin artması görünür rezistivite değerlerini maskelemektedir.
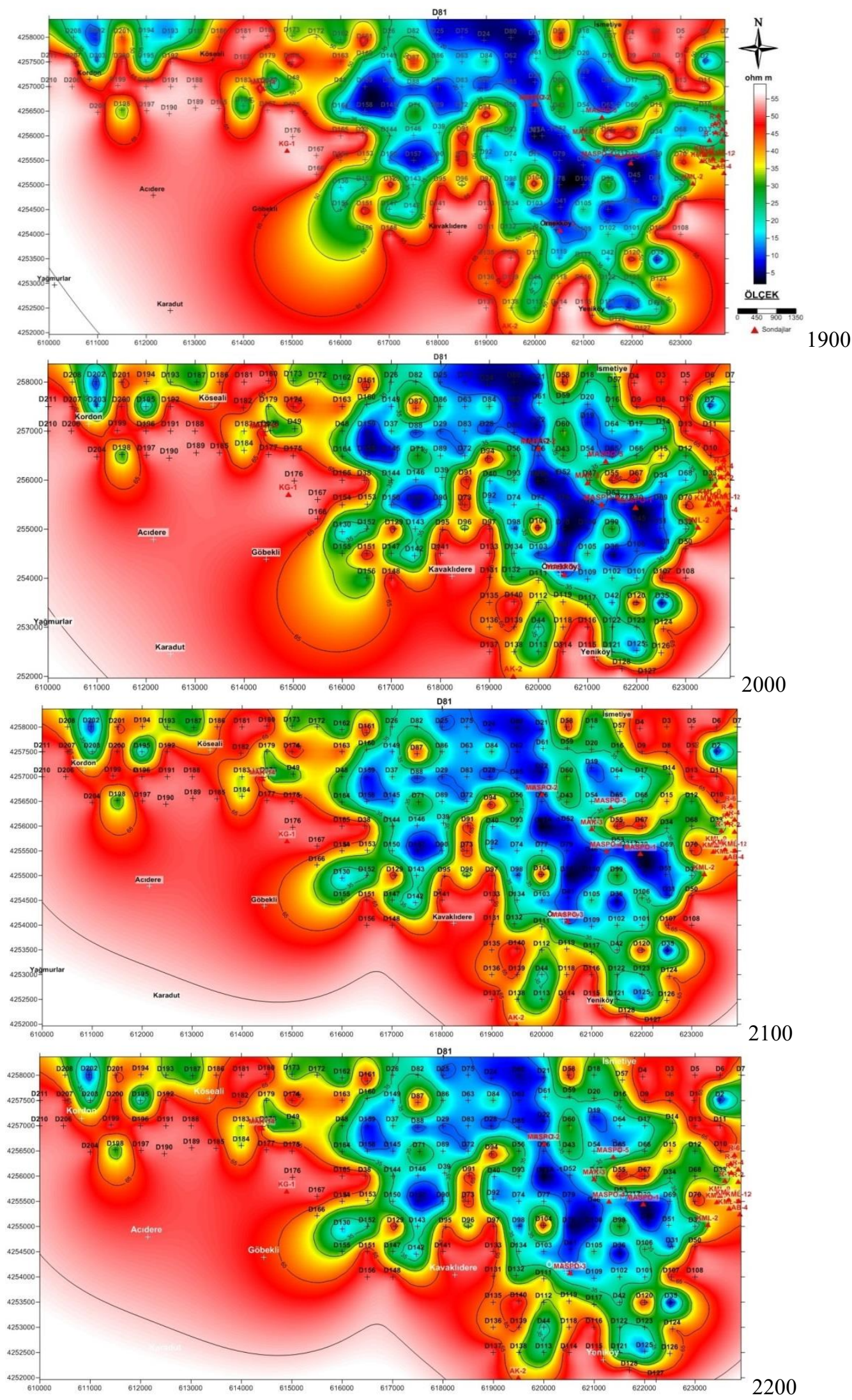

Şekil 7. AB/2=1900 - 2200 metre derinlikler için özdirenç seviye haritaları 

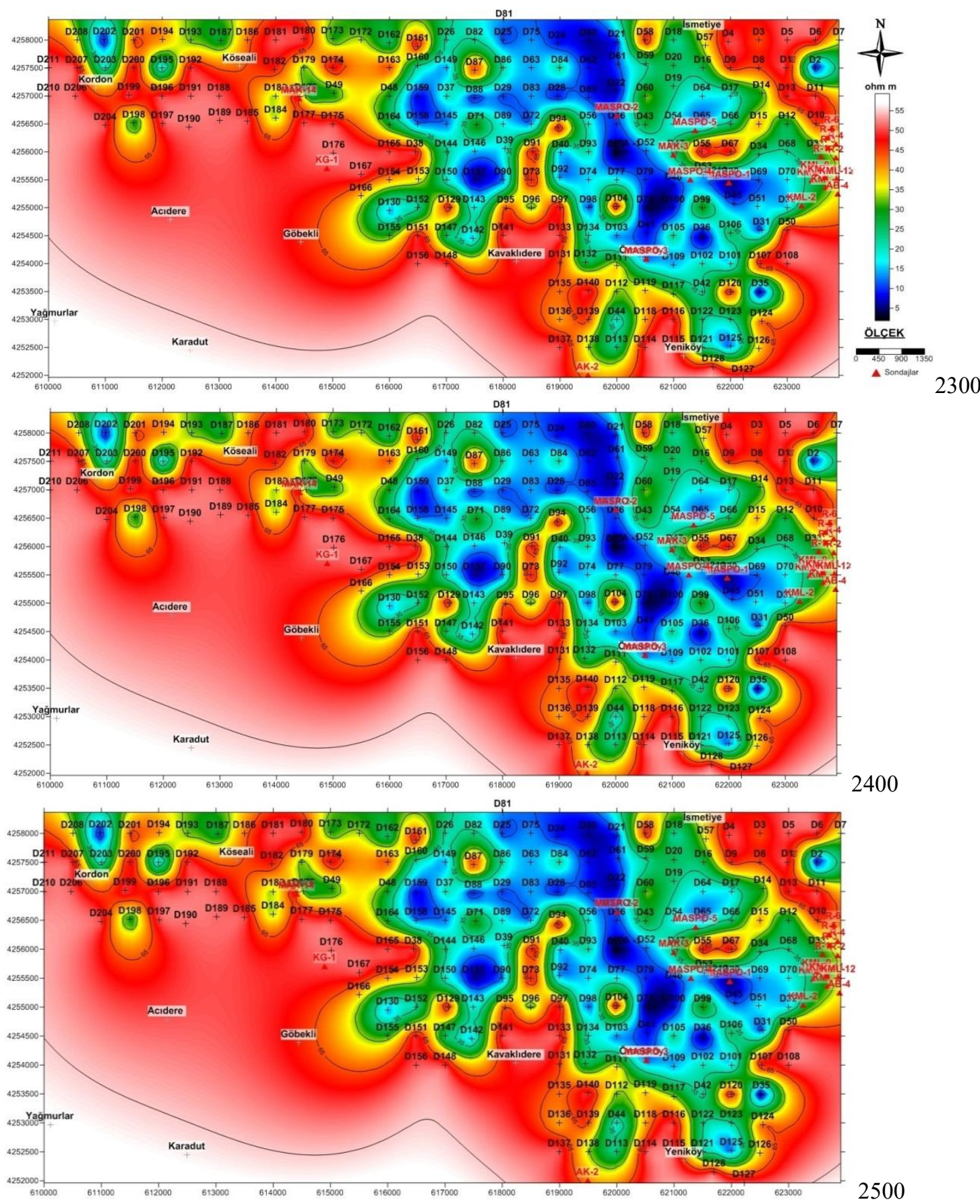

Şekil 8. AB/2=2300 - 2500 metre derinlikler için özdirenç seviye haritaları

\subsection{Temel Derinliği Haritası ve Yorumu}

Yüksek özdirençli jeoelektrik temel, çalışma sahasının jeolojik temelini oluşturan Menderes Masifi metamorfikleri ve içerisindeki granitler ile deneştirilebilir. Temelin derin olduğu yerlerde, temel üzerindeki seviyelerin kalınlıkları ince ise ayrılmaları mümkün değildir. Bu nedenle, havza tabanındaki rezistif (yalıtkan) seviye bütünü ile jeoelektrik temel olarak yorumlanmıştır.

Bulunan temel derinliklerinden, taban topoğrafyası veya temel kaya derinlik haritaları hazırlanabilir. Eğer taban topoğrafyası haritalanacak ise, her bir lokasyon için bulunan derinlikten, o lokasyonun kotu çıkarılır ve bu şekilde o lokasyonun kotu bulunur. Her lokasyon için bulunan kot değerlerinden, taban topoğrafyası haritası hazırlanır. Temel topoğrafya haritası, her bir lokasyon için bulunan yükselti değerinden hazırlanmaktadır.

Çalışma alanı için hazırlanan temel derinlik haritasında (Şekil 9), 1D model sonucu bulunan derinlikler doğrudan kullanılmıştır. Temel derinlik haritalarındaki eş yükselti eğrilerinin dağılımından, çalışma alanı için çok sayıda fay yorumu yapılmıştır. Bunlardan bazıları, yüzey jeolojisi çalışmalarında belirlenen özellikle grabenin güney kanadındaki fayların beklenen yönelimleri ile uyumluluk göstermektedir. Özdirenç değerleri, çalışma alanının güney kısmında belirgin bir şekilde yükselmiştir. Bu yüksek değerler, KB-GD uzanımlı kırık/çatlak sistemleri ile sınırlanmaktadır. 


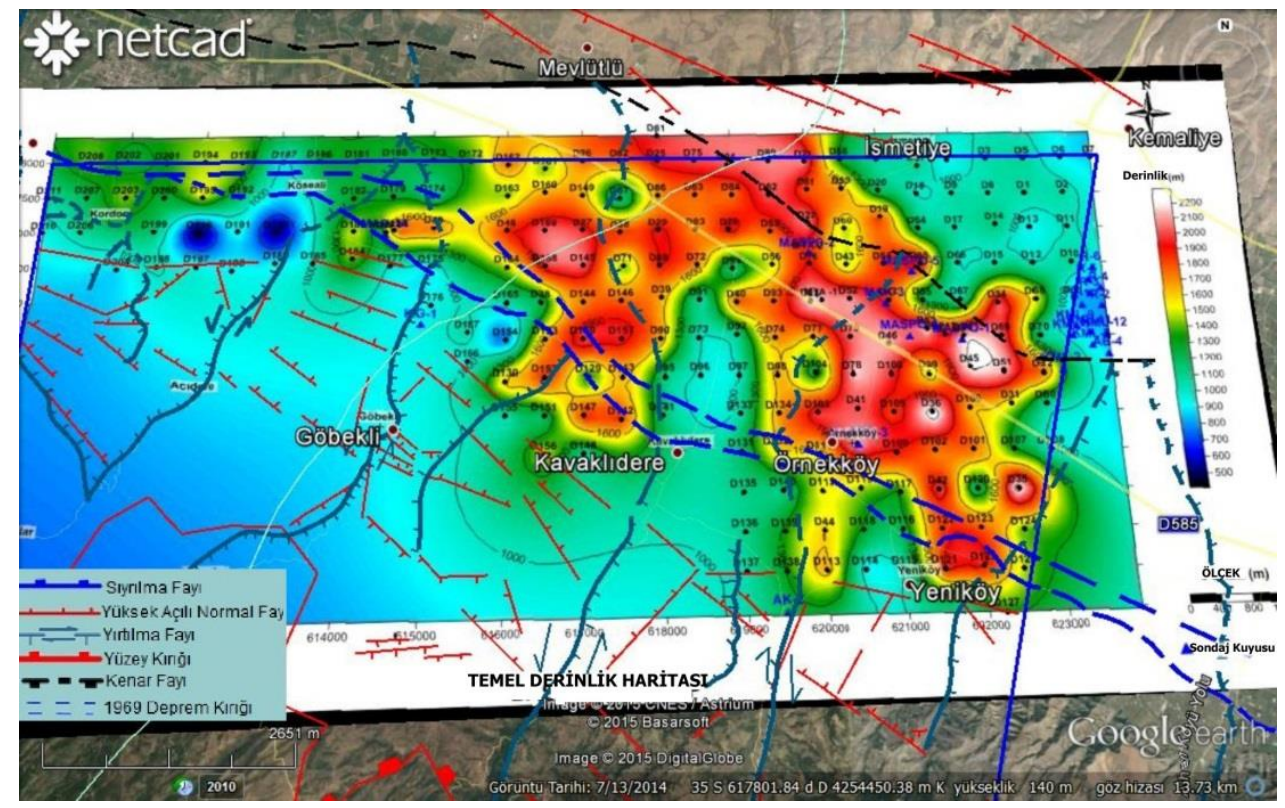

Şekil 9. Temel derinliğinin ruhsat alanındaki faylarla ilişkisi

\section{4. Özdirenç Enine Kesitleri ve Yorumları}

Özdirenç enine kesitleri, bir profil boyunca yer alan DES noktalarının tamamı için ölçülen özdirenç değerleri kullanılarak hazırlanmaktadır. Bu enine kesitler, hem yatay hem de düşey yönlü özdirenç dağılımlarını göstermektedir. Enine kesitlerde, kuramsal derinlikteki tektonik yapıları ve jeotermal alanları, özdirenç değerinin düşey ve yanal olarak değişimi şeklinde izlemek mümkündür. Çalışma alanının yeraltı jeolojisini yorumlamak amacıyla, tektonik yapı yönelimleri ile uyumlu olarak 14 adet özdirenç enine kesiti hazırlanmıştır (Şekil 10). Enine kesitler, bir profil boyunca yapılan DES ölçümlerinden elde edilen eğrilerden çalışma alanındaki jeolojik birimlerin kalınlık ve derinliklerini belirleyerek hazırlanmıştır. Enine kesitler hazırlanırken, en düşük özdirençli seviyelerin belirlenebilmesi için, en yüksek özdirenç değeri $80 \mathrm{ohm} . \mathrm{m}$ olarak sınırlandırılmıştır. Profil yönelimleri boyunca, olası stratigrafi, fay sistemleri, temel topoğrafyası ve yüksek sıcaklık bölgelerini açığa çıkarmak amacıyla, KB-GD yönünde 5 adet enine kesit ve GB-KD yönünde 9 adet enine kesit hazırlanmıştır (Şekil 11-14). Enine kesitlerin jeolojik yorumu ile çalışma alanında sayısız horst-graben sistemi varlığı belirlenmiştir. Buna göre, çalışma alanında çok sayıda fay oluşmuştur. Fayların, çoğunlukla KB-GD ve GB-KD yönünde olduğu ve bazı fayların birbirinin devamı olarak geliştiği görülmüştür. Fay sistemleri ile birlikte düşük özdirenç bölgeleri gelişmiştir. Diğer bir deyişle, fayların içinde dolaşan yüksek sıcaklıktaki akışkan, örtü kayaçlarda değişikliklere yol açmıştır.

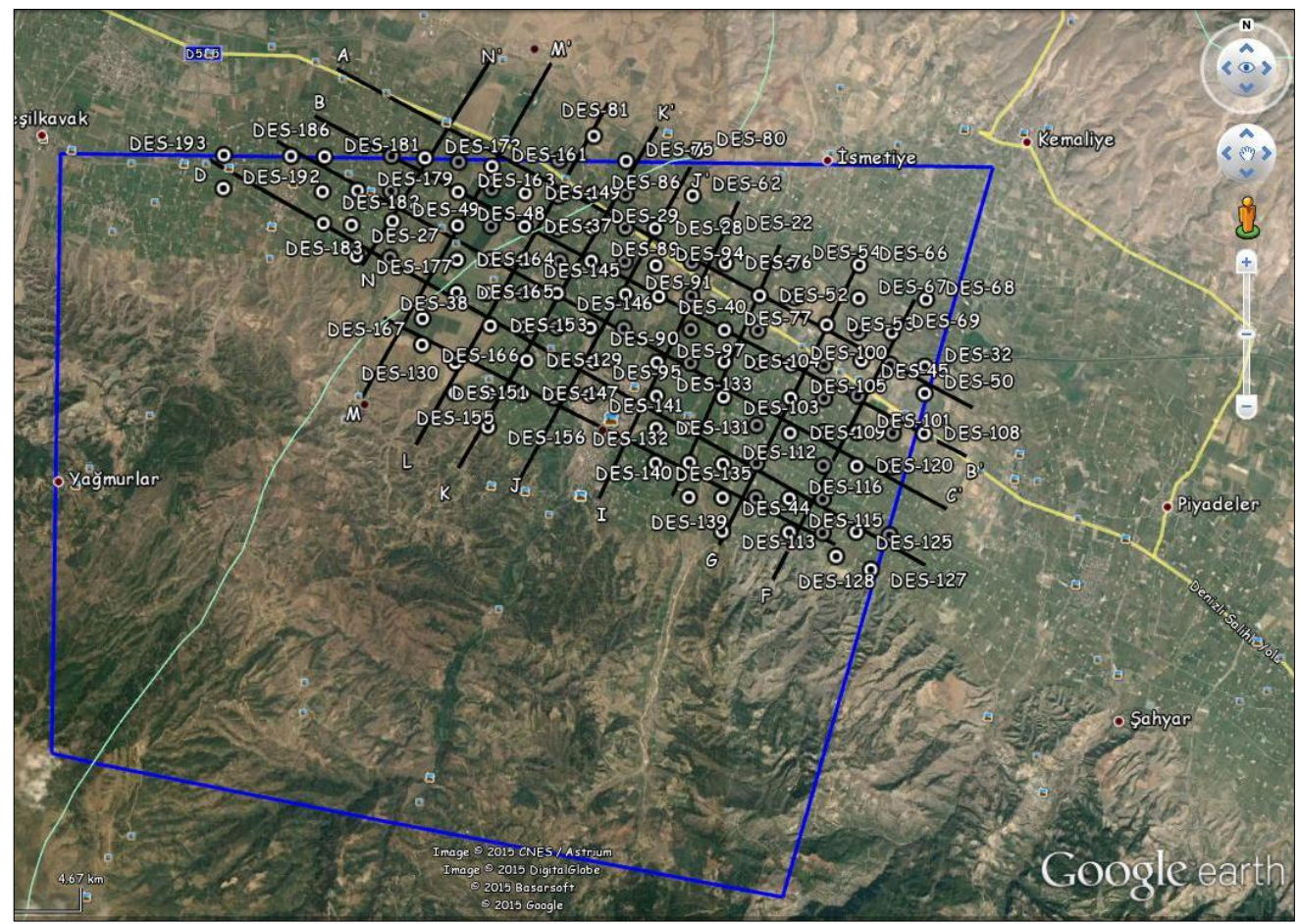

Şekil 10. Jeofizik ve jeolojik enine kesitlerin yer bulduru haritası 
European Journal of Science and Technology
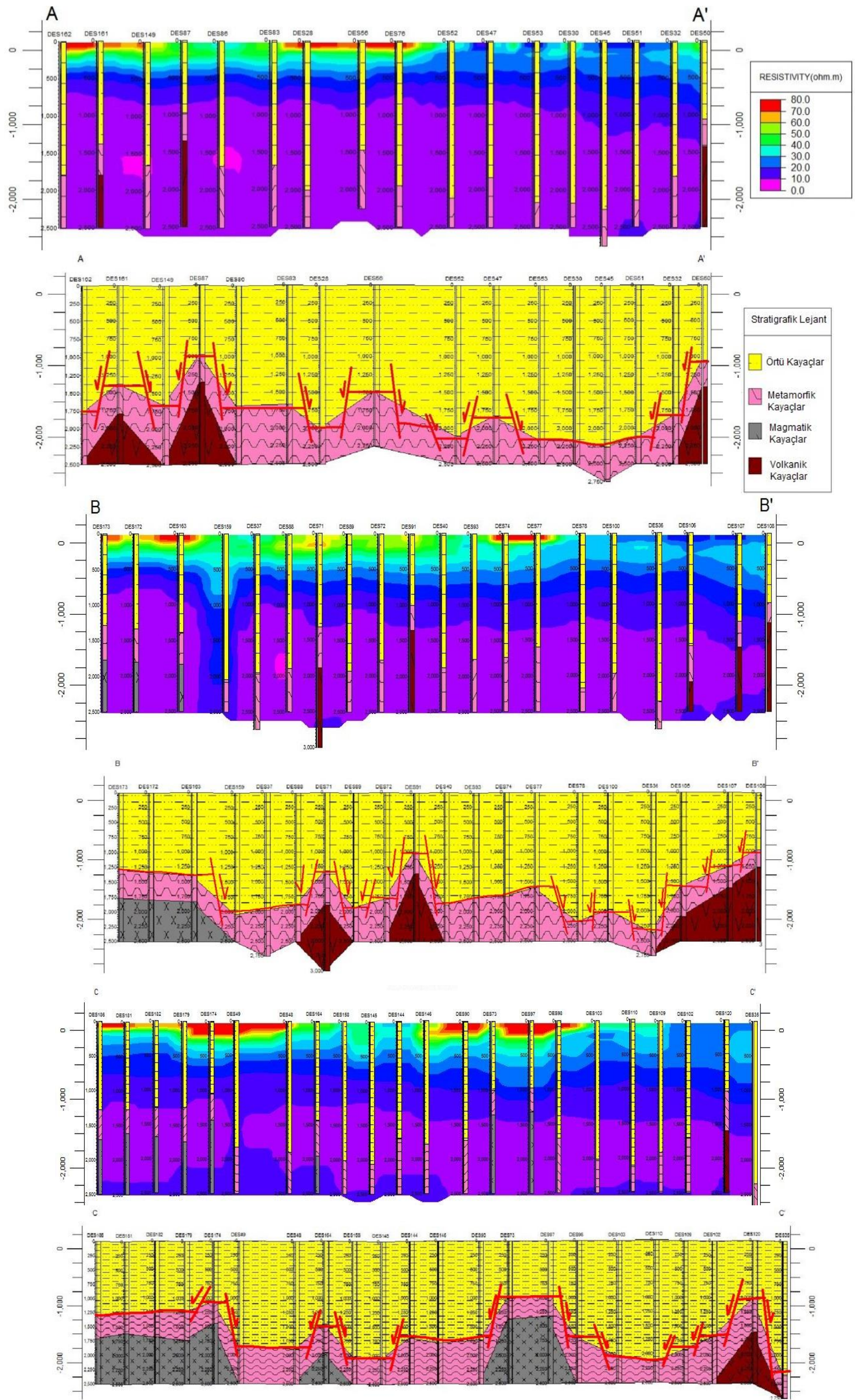

Şekil 11. A-A', B-B've C-C'jeofizik enine kesitleri ve jeolojik yorumlarl (kesitlerde, düssey ölçek metredir) 

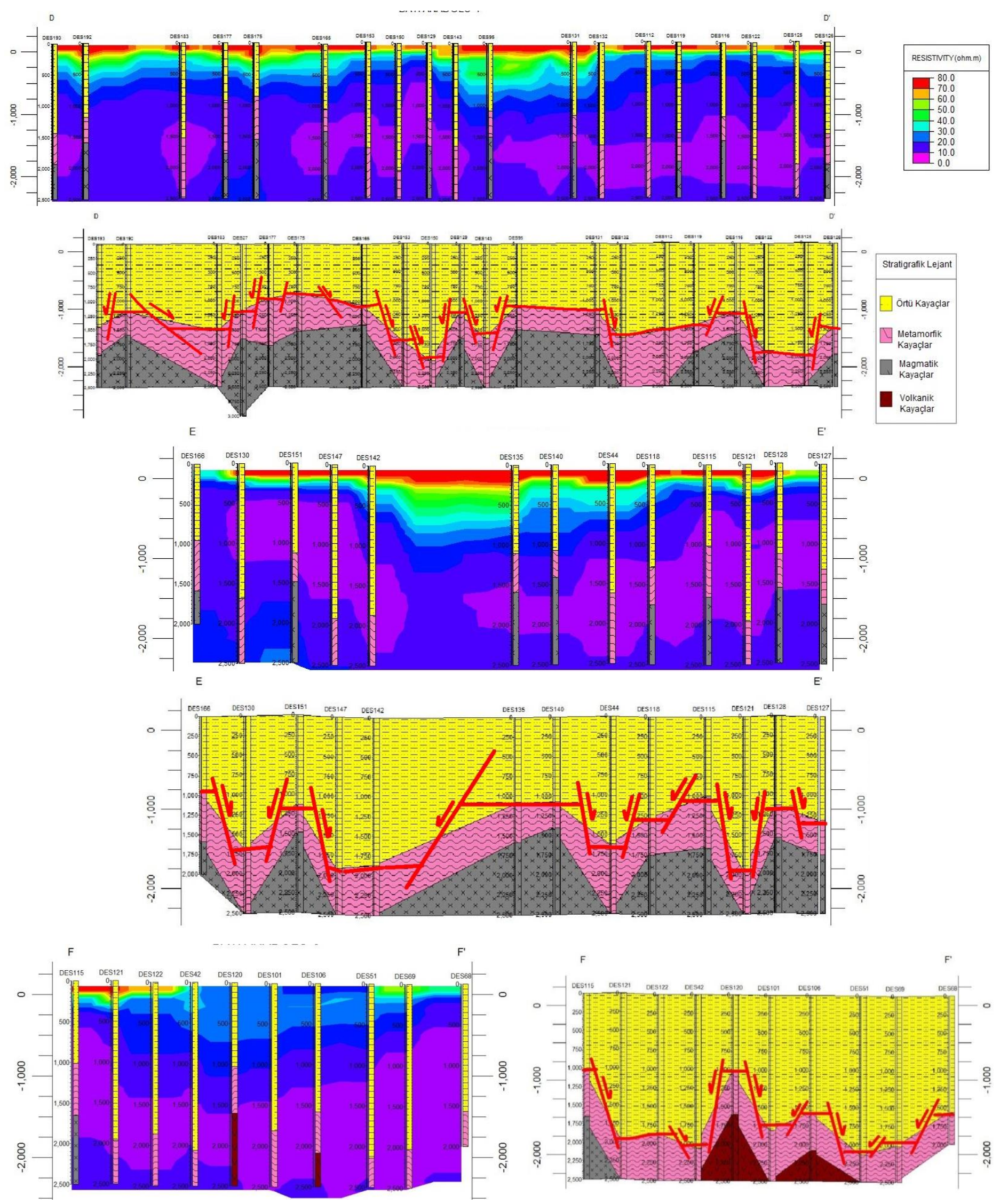

Şekil 12. D-D', E-E've F-F"jeofizik enine kesitleri ve jeolojik yorumları (kesitlerde, düşey ölçek metredir) 

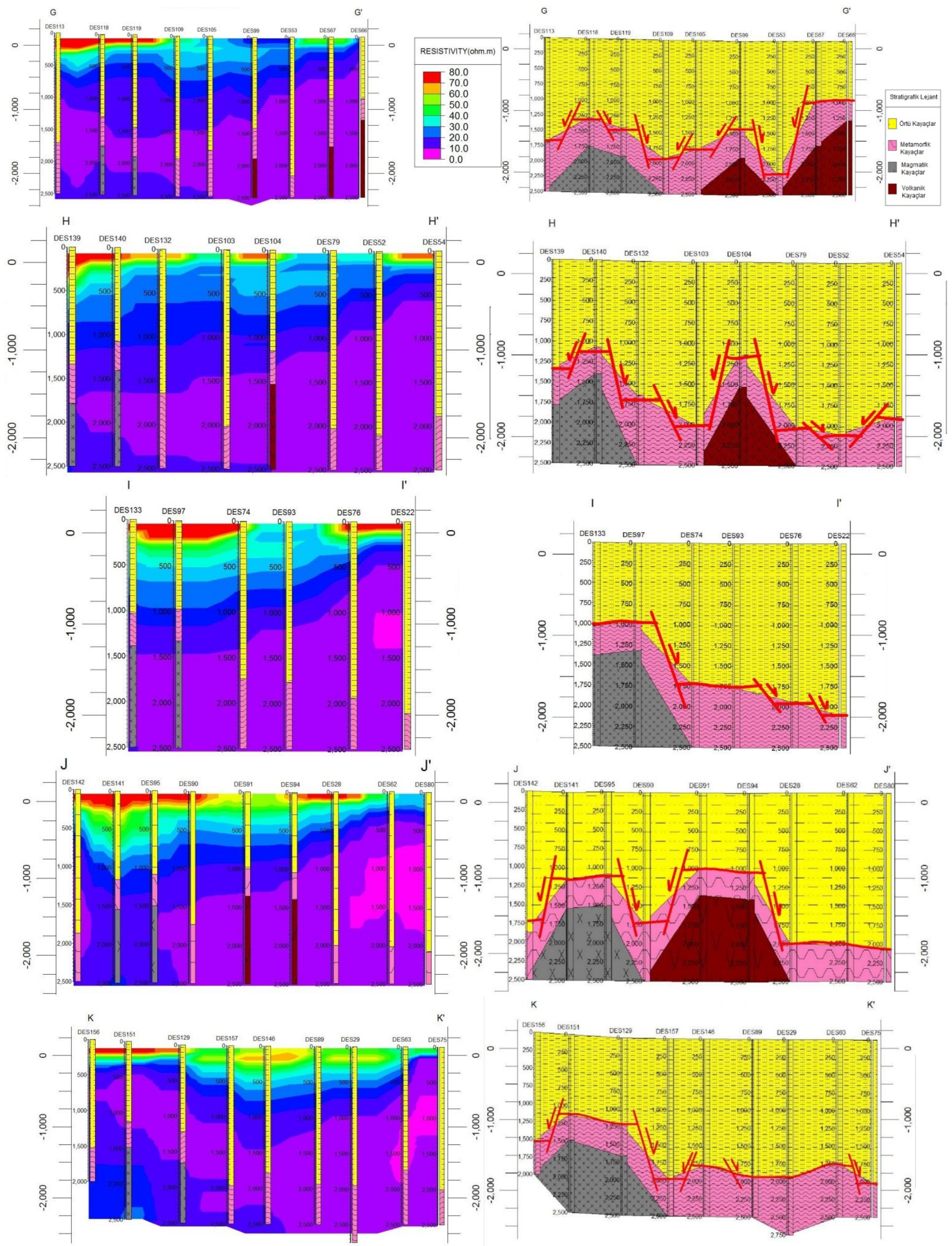

Şekil 13. G-G',H-H', I-I', J-J've K-K"jeofizik enine kesitleri ve jeolojik yorumları (kesitlerde, düşey ölçek metredir) 

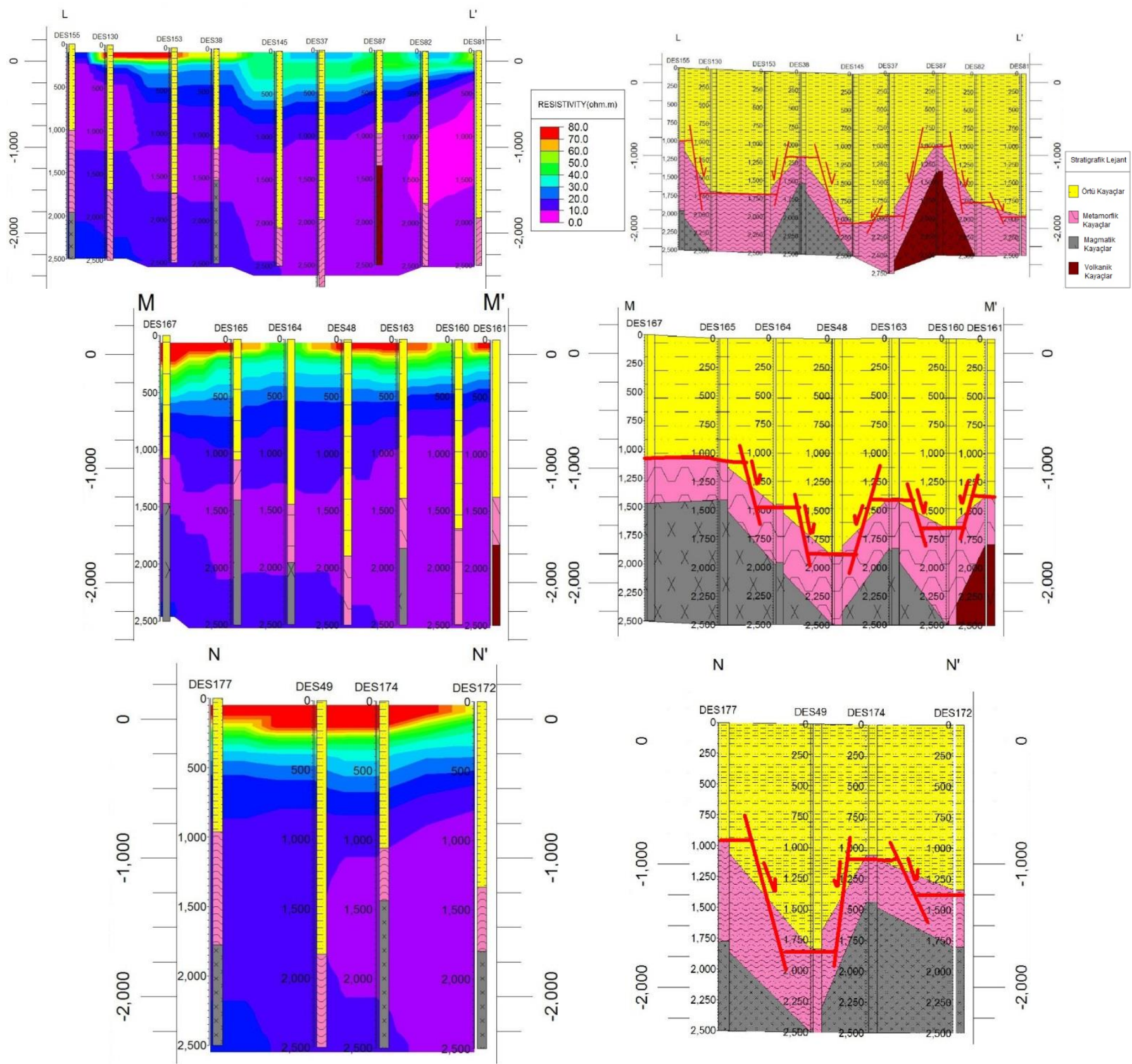

Şekil 14. L-L', M-M've N-N"jeofizik enine kesitler ve jeolojik yorumları (kesitlerde, düşey ölçek metredir)

Çalışma alanının yeraltı jeolojisini yorumlamak amacıyla, tektonik yönelimler ile uyumlu olarak 3D özdirenç ve stratigrafi modelleri (katı model ve fence diyagramı) hazırlanmıştır (Şekil 15 ve 16).
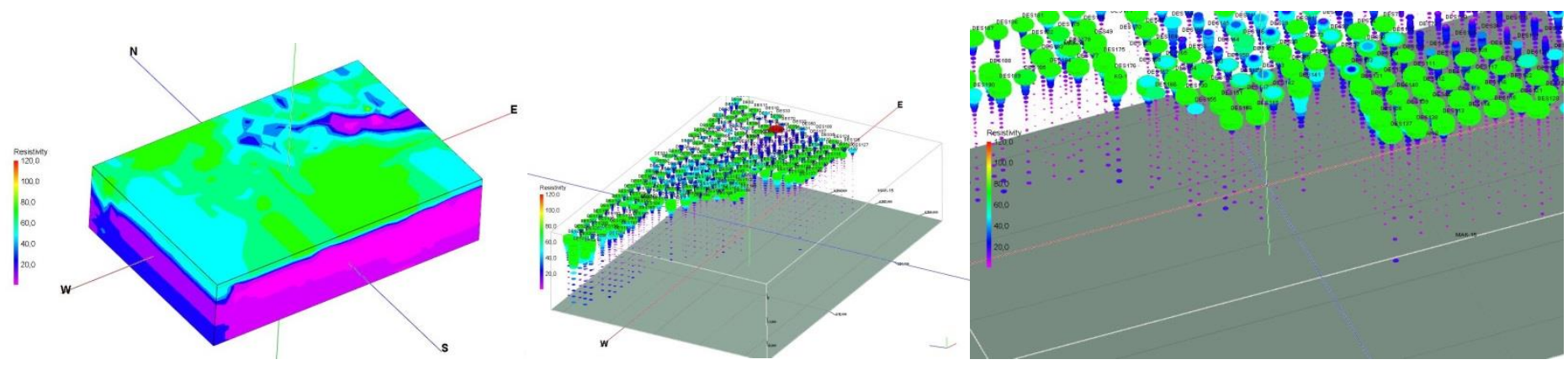

Şekil 15. Çalışma alanının 3D özdirenç modeli 

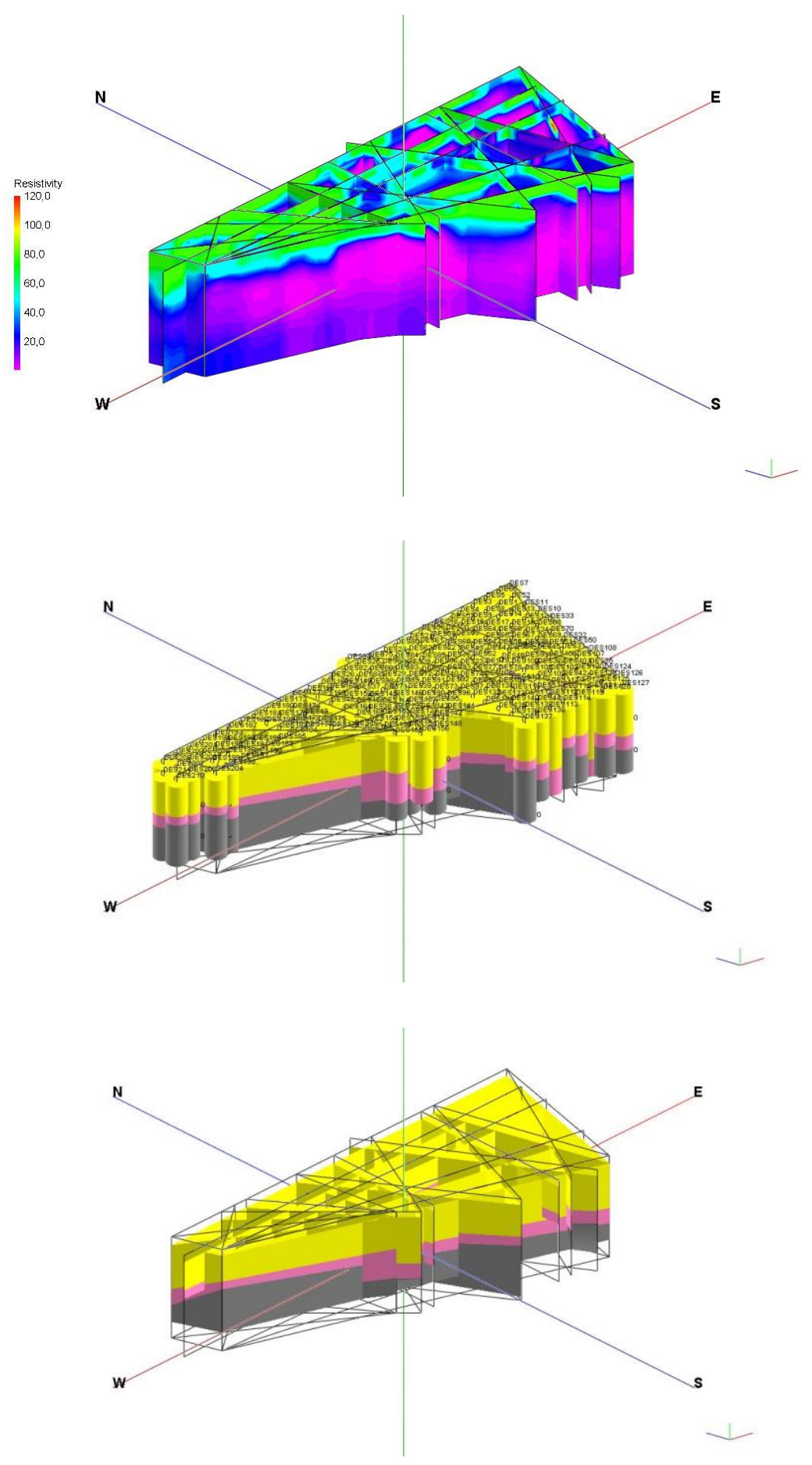

Şekil 16. İnceleme alanının özdirenç ve stratigrafi fence diyagramları

\subsection{Jeotermal Potansiyel}

Çalışma alanının daha çok orta ve kuzey kısmında yer alan farklı yönelimli fayların kesişim noktalarında, beklenen termal faaliyetleri belirlemek amacıyla yapılan jeofizik ölçümlerin yeniden değerlendirilmesi sonucunda potansiyel jeotermal rezervuarlar belirlenmiştir (Şekil 17, Blok-3 ve Blok-4). Jeolojik ve tektonik yapı ile jeofizik ölçümlerin birlikte değerlendirilmesi suretiyle, bu alanlarda delinecek sondajlardan yüksek sıcaklık ve yüksek debiye sahip akışkan elde edilebileceği düşünülmektedir. Çalışma alanındaki jeotermal rezervuarların, genel olarak kuzey yönelimli yırtılma fayları ile Gediz Sıyrılma Fayı'nın kesişme alanlarında bulunduğu tespit edilmiştir. Sıyrılma fayı ile kesişen yırtılma faylarındaki sol okun, jeotermal akışkanlar için kanal görevi gören genleşmeli yamulmaları (küçük çek-ayır havzaları) temsil ettiği görüşüne varılmıştır. Sol ok, sıyrılma fayı yüzeyi boyunca tavan bloğu sedimanter kayaçları ile temel kayacın gnaysları, mermerleri ve şistleri arasındaki farklılıktan kaynaklanmaktadır. Bu kesişimlerde yığışan mermer, jeotermal akışkanlar için iyi bir rezervuar oluşturur. Rezervuarların, sıyrılma fayının yırtılma fayları ile kesişimi boyunca hafifçe kuzeye doğru saptığı görülmüştür. Havza kenar fayı veya yırtılma fayları ile BKB atımlı normal faylar arasındaki karmaşık fay kesişimlerindeki basamaklar, jeotermal akışkanın yukarı doğru akışını sağlayabilir. Yüksek özdirenç değeri sunan kayaçlar, en düşük gözeneklilik ve geçirgenliğe sahip soğumuş tabakalara sokulmuş kayaçlar olarak yorumlanmıştır. 

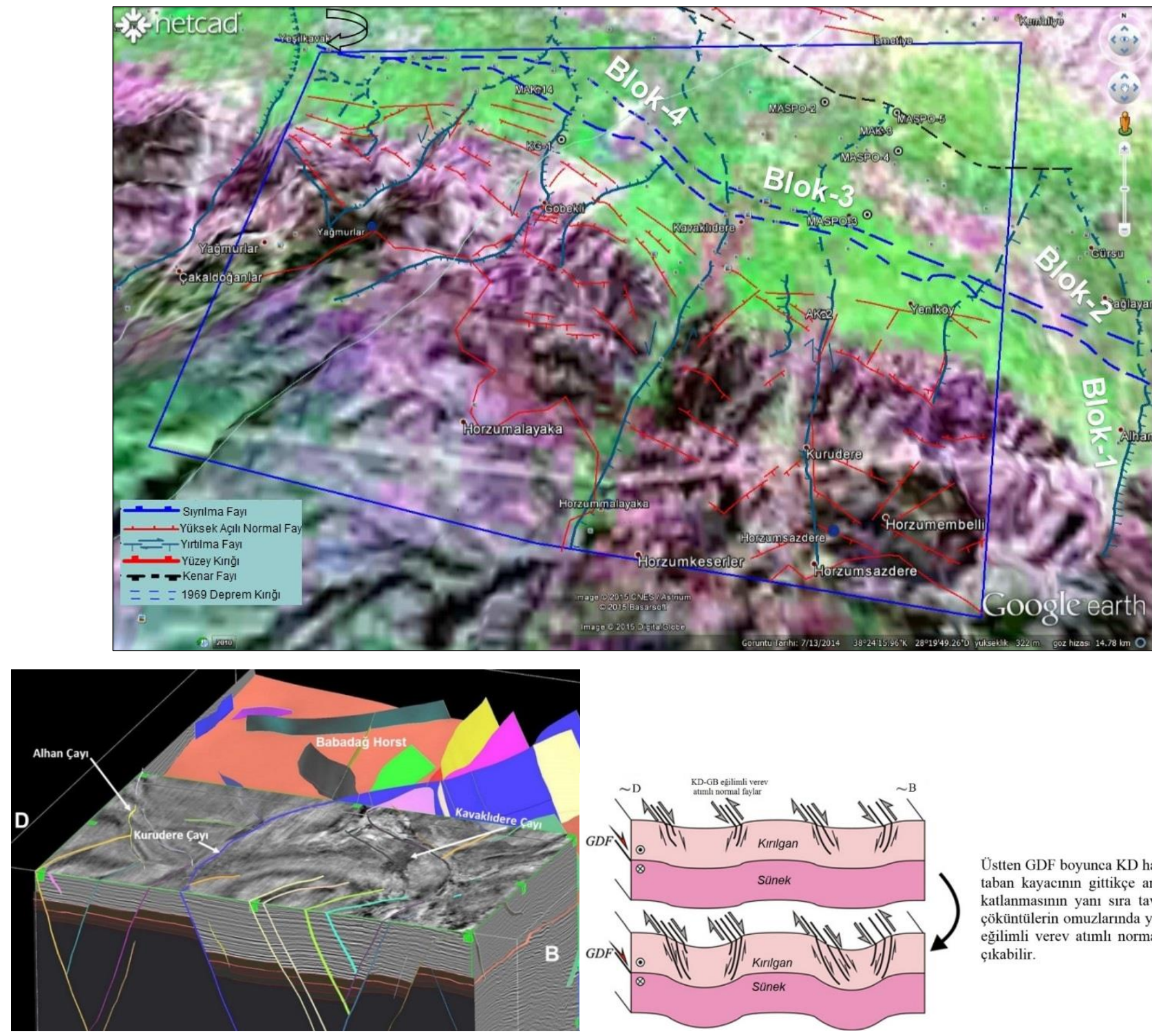

Üstten GDF boyunca KD hareketine kadar, taban kayacının gittikçe artan bir şekilde katlanmasının yanı sıra tavan bloğundaki ç̌ilimli verev atthls nor çıkabilir.

Şekil 17. Jeofizik ölçümler ve jeolojik yorumlar sonucunda ruhsat alanında tespit edilen potansiyel jeotermal rezervuarlar (Blok-3 ve Blok-4'teki mor ve bulanık renkli alanlar)

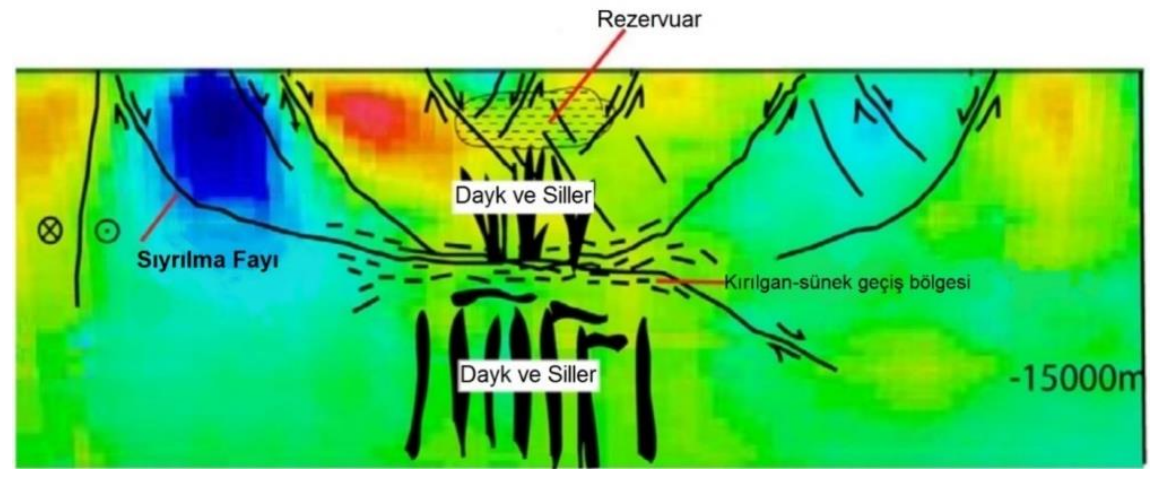

Şekil 18. Kavaklıdere jeotermal sahasındaki yapıların jeofizik ve jeolojik yorumunun özeti. Rezervuar bölgesi ile sistemin ısısını sağlayan dayklar ve sillerin yerleri yorumlanmıştır (Özdemir ve dĭ̆., 2017).

\section{Sonuçlar}

Jeolojik ve jeofizik verilerin birlikte değerlendirilmesi sonucunda, çalışma alanında çok sayıda horst-graben sisteminin varlığı belirlenmiştir ve birçok fay mevcuttur. Fay sistemleri, çoğunlukla KB-GD ve GB-KD yönlerinde gelişmişstir. Gelişen fay sistemleri, çoğunlukla birbirini takip eder şekildedir ve bazı faylar kollara ayrılmış durumdadır. Fay sistemleri ile birlikte düşük özdirençli zonlar vardır. Faylar içerisinde dolaşan yüksek sıcaklıktaki akışkan, örtü kayaçlarda alterasyonlara neden olmuştur. Diğer bir deyişle, 
jeotermal sistem ile ilişkili olan bölgelerin üst kısımlarında görülen düşük özdirenç değerleri, jeotermal etkinliğin özdirenç değerlerine yansımasıdır. Çalışma alanının KKD bölümünde, düşük özdirenç kapanımları tespit edilmiştir. 1600-1750 m derinliklerinde, jeotermal etki, belirgin hale gelmektedir. Derin seviyelerde, fay sistemleri ile ilgili düşük özdirenç alanlarının yaygınlığı, derinlik arttıkça jeotermal potansiyelin de arttığını göstermektedir. 1750-1900 m derinliklerinde, en düşük özdirenç dağılımı net olarak tespit edilebilmektedir. Bu derinliklerde, çalışma alanının K-KD bölümünde, jeotermal enerji potansiyelinin en güçlü belirteci olan rezistivite değeri en düşük değerlere ulaşmıştır. Havza dolgu çökellerinin derin seviyelerinde çok düşük özdirenç değerlerinin ölçülmesi, temel kaya içerisindeki yüksek sıcaklıklı akışkanların örtü kayada oluşturduğu alterasyon ve buna bağlı olarak oluşan elektrolitik ortamla açıklanabilir. 1900-2500 m derinliklerinde, durum oldukça farklıdır. Bu derinliklerdeki rezistivite değerlerinin göreceli yükselişi, bu seviyelerde temel birimlere girildiğini göstermektedir. Fakat, bu değerler, temel birimlerin rezistivitesini tam olarak yansıtmamaktadır. Rezistivitenin çok küçük değerlere kadar düşmesi, sahadaki sedimanter kayaçların kalınlı̆̆ının fazla olması ve buna bağlı olarak temel derinliğinin artması, görünür rezistivite değerlerini maskelemektedir. Yüksek özdirenç değeri veren kayaçlar, en düşük gözeneklilik ve geçirgenliğe sahip soğumuş tabakalara sokulmuş kayaçlar olarak yorumlanmıştır.

\section{Kaynakça}

Erden, F., 1965. Salihli-Manisa gravite etüdü. MTA Report No: 3931

Faulds, J., Bouchot, V., Moeck, I. and Oguz, K., 2009. Structural controls of geothermal systems in western Turkey: a preliminary report. Geotherm. Resou. Counc. Trans., 33, 375-383

Gürsoy, T., 1981. Turgutlu-Alaşehir Gravite Jeotermal Etüt Raporu. MTA Derleme No:6695

FNÇ Inc., 2012. Alaşehir Field Resistivity Survey Project Result Report, 122 p.

Koçyiğit, A., 2014. Active Tectonic Evaluation of Kavaklıdere (Manisa) License Areas. 52 p.

MTA, 2010a. Manisa ve Civarı Jeotermal Enerji Aramaları Jeofizik (Gravite-Manyetik) Etüd Raporu (Yıldırım, G.).

MTA, 2010b. Alaşehir (Manisa) Jeotermal Enerji Aramaları Projesi Jeofizik MT (magnetotelluric) AMT (audiomagnetic) Elektrık Özdirenç (VES) ve Radyometrik (gamma-ray spektrometre) Etüd Raporu (Bostan, S., Karzaoğlu, H. ve Küçük, M.).

MTA, 2011a. Manisa Alaşehir Jeotermal Enerji Sahası MAK-14 ve MAK-3 Kuyularının Özet Değerlendirilmesi (Dünya, H.).

MTA, 2011b. Manisa Alaşehir Jeotermal Enerji Sahası MAK-15 Jeotermal Kuyu Geliştirme ve Bitirme Test Raporu (Dünya, H. ve Bilgiç, Ö.).

MTA, 2011c. Manisa Alaşehir Jeotermal Enerji Sahası MAK-14 Jeotermal Kuyusunun RCHP ile Temizliği, Asitleme-Geliştirme ve Bitirme Test Raporu (Dünya, H., Bilgiç, Ö. ve Akgun, B.).

MTA, 2011d. Manisa Alaşehir Kavaklıdere Jeotermal Enerji Sahası MAK-2011/3 Kuyu Tamamlama Test Raporu (Dünya, H., Bilgiç, Ö. ve Akgun, B.).

MTA, 2011e. Manisa Civarı (Alaşehir-Kavaklıdere) Jeotermal Enerji Aramaları Projesi (Proje No: 2010-33-13-04-7) MAK-2010-14, MAK-2010-15 ve MAK-2011-03 Jeotermal Sondajları Kuyu Bitirme ve Test Raporu (Burçak, M. ve Dünya, H.).

MTA, 2011f. Manisa Alaşehir-Kavaklıdere Sahası Jeotermal Etüt Raporu (Burçak, M., Bostan, S., Karzaoğlu, H., Yıldırım,G. ve Küçük, M.)

Özdemir, A., 2015. Kavaklıdere (Alaşehir/Manisa) Jeotermal Sahasının Yeni Yeraltı Jeolojisi ve Jeotermal Modeli. 623 s. (Yayımlanmamış)

Özdemir, A., Yasar, E. and Cevik, G., 2017. An importance of the geological investigations in Kavaklidere geothermal field (Turkey). Geomechanics, Geophysics, Geo-Energy and Geo-Resources, 3, 29-49

Özdemir, A. and Palabıyı, Y., 2019a. Role of scissor faults in geothermal reservoir occurrence. II. Ulusal Mühendislikte Bilimsel ve Mesleki Çalışmalar Kongresi , 07 - 10 Kasım 2019, Ankara (baskıda)

Özdemir, A. and Palabıyık, Y., 2019b. A new method for geological interpretation of 3D MT (Magnetotelluric) depth maps of hightemperature and deep geothermal fields: A case study from Western Turkey. $2^{\text {nd }}$ International Congress on Applied Sciences, 2830 October 2019, Ankara, 28-42

Palabiyı, Y. and Özdemir, A., 2019. Potential of detachment folds to become a geothermal reservoir in a horst. II. Ulusal Mühendislikte Bilimsel ve Mesleki Çalışmalar Kongresi, 07 - 10 Kasım 2019, Ankara (baskıda)

Şener, Ç., Yücel, M. ve Karagöz, Ş., 1993. Manisa Turgutlu-Salihli-Alaşehir Sahası Jeotermal Enerji Aramaları Jeofizik Etütleri (Doğru Akım Özdirenç-CSAMT-Sismik) Raporu, MTA Derleme No:9625

Şimsek, Ş., 2012. Advisory Report on Geological-Hydrogeological-Geophysics and Potential Assessment Evaluation of ManisaAlaşehir-Kavaklıdere Geothermal License Areas and Determination of the Exploration/Production/Reinjection Well Locations. $272 \mathrm{p}$.

Türk, S., 2014. Sesmic Structure and Tectonics of the Alaşehir-Gediz Graben, Western Turkey, Miami University, Master Thesis of Science. 42 p.

Ünal, A. ve Havur, E., 1971. Alaşehir-Salihli Bölgesinin Jeotermik Enerji Yönünden Detay Jeoloji Etüdü. MTA Raporu No ; 4678

Yazman, M.K. ve İztan, H., 1990. Alaşehir'in (Manisa) Jeolojisi ve Petrol Olanakları. TPAO Exploration Group, unpublished technical report, $18 \mathrm{p}$.

Yazman, M.K., Güven, A., Ermiş, Y., Yılmaz, M., Özdemir, İ., Akçay, Y., Gönülalan, U., Tekeli, Ö., Aydemir, V., Sayıll, A., Bat1, Z., İztan, H., Korucu, Ö., 1998. Alaşehir Grabeni'nin ve Alaşehir-1 Prospektinin Değerlendirme Raporu. TPAO Exploration Group, unpublished technical report, $142 \mathrm{p}$.

Yılmazer, S. Pasvanoğlu, S. and Vural, S., 2010. The relation of geothermal resources with young tectonics in the Gediz Graben (West Anatolia, Turkey) and their hydrogeochemical analyses. Proceedings World Geothermal Congress 2010, 25-29 April 2010,

Bali, Indonesia, $1151-1161$

WesternGeco Inc., 2012. Magnetotelluric Survey, Alaşehir, Turkey, 3D Modeling Report, 45 p. 